\title{
Bacteriological Profile and Antibiotic Sensitivity Pattern of Bacterial Pathogens Isolated from Pus Samples
}

\author{
Qursheed Sultana $^{1 *}$, Ajaz Hussain ${ }^{1}$, Maimoona Mustafa ${ }^{1}$ and \\ Mohammed Abdur Rab Ansari \\ ${ }^{1}$ Department of Microbiology, ${ }^{2}$ Deccan College of Medical Sciences, \\ Hyderabad, Telangana, India \\ *Corresponding author
}

\section{A B S T R A C T}

\section{Keywords}

Antimicrobial susceptibility,

Bacteriological profile, Pyogenic infection, Pus

Culture,

Antibiogram

\section{Article Info}

Accepted:

05 June 2020

Available Online:

10 July 2020
Bacterial infections are considered as the common causes for the pyogenic infections. Various studies have shown that there is an inconsistency in bacteriological profile of the isolates and antibiotic resistance pattern. This demands for the periodic monitoring of the bacterial isolates and their antimicrobial sensitivity pattern. The present study aims to analyze the bacterial pathogens isolated from the pus samples and their antibiotic susceptibility pattern. This is a prospective, observational, single-centered study, conducted in a tertiary care hospital in Hyderabad for a period of 2 years, from August 2016 to 2018.A total of 410 pus samples were brought to the Microbiology lab from different inpatient and outpatient departments and were processed to identify the pathogens and their anti-microbial sensitivity pattern using Kirby Bauer disc diffusion method. The data analyzed was presented in percentages. Out of 410 samples analyzed, $257(62.68 \%)$ were found to be culture positive. Among 257 culture positive isolates, $56.78 \%$ were gram negative bacteria and the rest $43.16 \%$ were gram positive bacteria. However, the most commonly isolated pathogens were Staphylococcus aureus followed by Klebsiella and E. coli. The gram positive bacteria were found to be most susceptible to vancomycin and linezolid, whereas gram negative isolates were most susceptible to imipenem, meropenem and colistin. The most common pathogen identified was Staphylococcus aureus. However, gram negative bacteria were predominant. The emerging bacterial resistance for various antimicrobial agents complicates the management of pyogenic infection. Periodic susceptibility data from various studies helps clinicians to select proper antibiotic for the isolates, thus preventing the emergence of the drug resistance stains.

\section{Introduction}

Skin acts as an effective deterrent for infections. Although, various bacteria inhabit our skin, nasopharynx, stomach and other parts of the body, they are unlikely to cause infections due to the presence of first line defense mechanism of the body. ${ }^{(1)}$ This defense mechanism can be altered by various factors such as surgical procedures, trauma, burns and diseases leading to the skin penetration by the pathogens. ${ }^{(2)}$ 
Skin infections are not uncommon and the severity ranges from less significant pyoderma infections to very rare and lifethreatening necrotizing infections. Various microorganisms (such as bacteria, fungi and parasites) can cause skin infections. ${ }^{(3)}$

Pus formation commonly encountered in bacterial infections, is usually due to the systemic inflammation. Bacterial pathogens leading to purulence or pus formation are called as pyogenic bacteria and such infections are called as pyogenic infections. ${ }^{(4,5)}$ The most prevalent gram positive pyogenic bacteria include Staphylococcus aureus, Streptococcus pyogenes and Enterococci and gram negative pyogenic bacteria include - Escherichia coli, Klebsiella species, Proteus and Pseudomonas species. ${ }^{(6)}$

Antibiotic therapy plays a cardinal role in the treatment of such infections. Many studies have shown that though the bacteriological profile from pus samples is consistent, but there are variations in the antibiotic resistance profile obtained from pyogenic pathogens. ${ }^{(7)}$ Mis-prescriptions and improper use of antibiotics has led to the continuous increase in the emergence of the multi drug resistant microorganisms. As a result, there is increase in the rate of prolonged illness and risk of spreading the resistant strains. ${ }^{(8,9)}$

The aim of this study is to identify the pyogenic bacteriological profile and antibiotic sensitivity of the isolates from pus samples at a tertiary care hospital.

\section{Materials and Methods}

This is a prospective, single centered study conducted for a period of 2 years from 2016 to 2018 in the Microbiology Department of Princess Esra Hospital, Hyderabad. The ethical committee approval was obtained before the initiation of the study. A total of 410 samples were collected by sterile syringe aspiration and swabs from various inpatient and outpatient wards of the hospital, and were analyzed for bacterial growth isolates and their sensitivity profile for antibiotics in Microbiology laboratory as per the standard microbiological protocols.

The pus samples were inoculated on blood agar and Mac Conkey's agar plates at 35$37^{\circ} \mathrm{C}$ for about $24-48$ hours. The primary identification of the bacterial colonies from the positive cultures was done with the help of colony appearance and hemolysis. Furthermore, identification and characterization of the bacterial isolates is performed by using colony morphological characteristics, hemolysis, gram staining and biochemical tests such as catalase test, coagulase test, indoletest, methyl red (MR) test, citrate utilization test, urease hydrolysis test and triple sugar iron agar.

Antibiotic susceptibility pattern of the isolates was determined by using Kirby-Bauer disc diffusion test recommended by Clinical and Laboratory Standards Institute (CLSI). An inoculum was prepared for each bacterial isolate by adjusting the turbidity to 0.5 McFarland standard, which was then spread on Muller-Hinton agar plates. The antibiotic discs were then set on the agar plates and incubated overnight at $35-37^{\circ} \mathrm{C}$ for $24-48$ hours. The zones of inhibition for the antibiotics were measured in $\mathrm{mm}$ and were further classified according to CLSI tables and guidelines.

\section{Results and Discussion}

The results were analyzed statistically using MS excel and was presented in terms of percentages. 
Table.1 Age distribution

\begin{tabular}{|c|c|c|}
\hline Age group (years) & Number of patients & Percentage of patients \\
\hline $\mathbf{0 - 1 0}$ & 15 & 3.65 \\
\hline $\mathbf{1 1 - 2 0}$ & 61 & 14.87 \\
\hline $\mathbf{2 1 - 3 0}$ & 85 & 20.73 \\
\hline $\mathbf{3 1 - 4 0}$ & 64 & 15.60 \\
\hline $\mathbf{4 1 - 5 0}$ & 76 & 18.53 \\
\hline $\mathbf{5 1 - 6 0}$ & 62 & 15.12 \\
\hline $\mathbf{6 1 - 7 0}$ & 27 & 6.58 \\
\hline $\mathbf{7 1 - 8 0}$ & 15 & 3.65 \\
\hline $\mathbf{8 1 - 9 0}$ & 5 & 1.21 \\
\hline
\end{tabular}

Fig.1 Gender distribution

Mimhor nf notionte

$180,44 \%$

$230,56 \%$

Males Females

Table.2 Department wise distribution of pus samples

\begin{tabular}{|l|c|c|c|}
\hline S.No. & Department & No. of isolates & Percentage of isolates \\
\hline $\mathbf{1 .}$ & General Surgery & 113 & 27.5 \\
\hline $\mathbf{2}$ & Dermatology & 5 & 1.21 \\
\hline $\mathbf{3}$ & Pediatrics & 15 & 3.65 \\
\hline $\mathbf{4}$ & Casualty & 44 & 10.73 \\
\hline $\mathbf{5}$ & Plastic surgery & 38 & 9.26 \\
\hline $\mathbf{6}$ & General Medicine & 34 & 8.29 \\
\hline $\mathbf{7}$ & Gynaecology & 25 & 6.09 \\
\hline $\mathbf{8}$ & Gastroenterology & 20 & 4.87 \\
\hline $\mathbf{9}$ & Orthopedics & 27 & 6.58 \\
\hline $\mathbf{1 0}$ & Urology & 20 & 4.87 \\
\hline $\mathbf{1 1}$ & Cardiology & 12 & 2.92 \\
\hline $\mathbf{1 2}$ & Neurology & 15 & 3.65 \\
\hline $\mathbf{1 3}$ & CCU & 9 & 2.19 \\
\hline $\mathbf{1 4}$ & MICU & 13 & 3.17 \\
\hline $\mathbf{1 5}$ & Respiratory & 12 & 2.92 \\
\hline $\mathbf{1 6}$ & ENT & 8 & 1.95 \\
\hline
\end{tabular}


Table.3 Distribution of samples according to the growth of isolates

\begin{tabular}{|c|c|c|c|}
\hline S. No. & Sample Distribution & Number of Samples & $\begin{array}{c}\text { Percentage of } \\
\text { samples }\end{array}$ \\
\hline $\mathbf{1 .}$ & Culture Negative & 153 & 37.31 \\
\hline $\mathbf{2 .}$ & Culture Positive & 257 & 62.68 \\
\hline $\mathbf{3 .}$ & Total & 410 & 100 \\
\hline
\end{tabular}

Table.4 Distribution of gram positive and gram-negative bacteria

\begin{tabular}{|l|l|c|c|}
\hline S.No. & Isolated Bacteria & Number of subjects & Percentage of subjects (\%) \\
\hline I. & Gram Negative Bacteria & 146 & 56.78 \\
\hline & Klebsiella species & 96 & 37.35 \\
\hline & Escherichia coli & 28 & 10.89 \\
\hline & Pseudomonas species & 11 & 4.28 \\
\hline & Proteus species & 5 & 1.94 \\
\hline & Acinetobacter species & 2 & 0.77 \\
\hline II. & Citrobacter species & 4 & 1.55 \\
\hline $\mathbf{1}$ & Gram Positive Bacteria & 43.16 \\
\hline & Staphylococcus species & 111 & 5.44 \\
\hline & $\begin{array}{l}\text { Methicillin resistant Staphylococcus } \\
\text { aureus } \text { (MRSA) }\end{array}$ & 14 & 32.29 \\
\hline & $\begin{array}{l}\text { Methicillin sensitive Staphylococcus } \\
\text { aureus } \text { (MSSA) }\end{array}$ & 83 & 1.55 \\
\hline & $\begin{array}{l}\text { Methicillin resistant coagulase } \\
\text { negative Staphylococcus (MRCONS) }\end{array}$ & 4 & 3.50 \\
\hline & $\begin{array}{l}\text { Methicillin sensitive coagulase } \\
\text { negative Staphylococcus (MSCONS) }\end{array}$ & 9 & 0.38 \\
\hline 2. & Streptococcus species & 1 & 100 \\
\hline & Total & 257 & \\
\hline
\end{tabular}


Fig.2 Percentage of grame-positive and gram-negative isolates

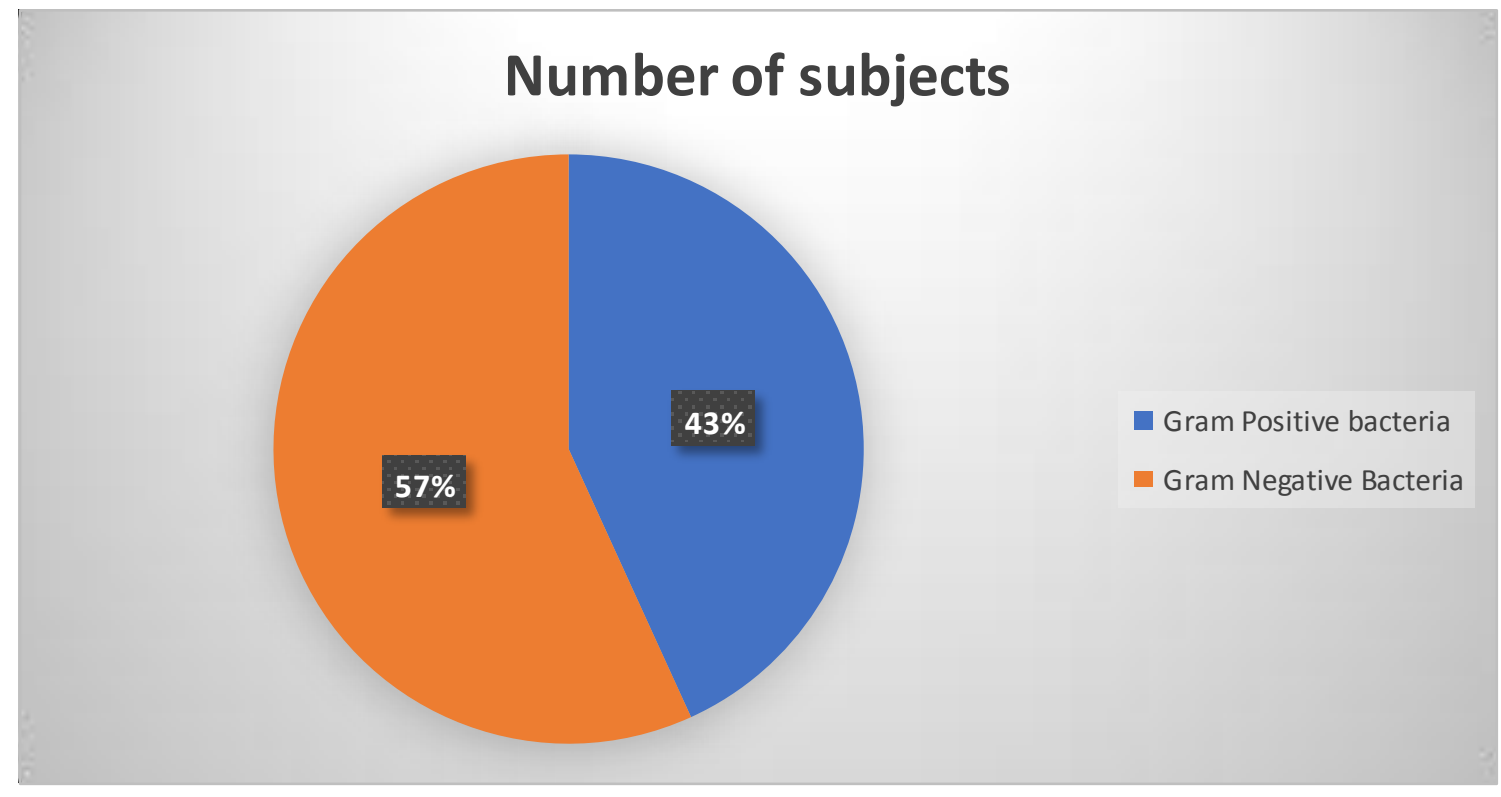

Table.5 Antibiotic sensitivity of gram negative isolates

\begin{tabular}{|c|c|c|c|c|c|c|}
\hline S.No & Antibiotic & $\begin{array}{c}\text { Klebsiella } \\
\mathbf{n = 9 6}\end{array}$ & $\begin{array}{c}\mathbf{E . ~ c o l i} \\
\mathbf{n = 2 8}\end{array}$ & $\begin{array}{c}\text { Pseudomonas } \\
\mathbf{n = 1 1}\end{array}$ & $\begin{array}{c}\text { Proteus } \\
\mathbf{n = 5}\end{array}$ & $\begin{array}{c}\text { Citrobacter } \\
\mathbf{n = 2}\end{array}$ \\
\hline $\mathbf{1}$ & Ampicillin & $25(26.04)$ & $8(28.57)$ & $3(27.27)$ & $1(20)$ & 0 \\
\hline $\mathbf{2}$ & Ampicillin/Salbactum & $64(66.67)$ & $21(75)$ & $6(54.54)$ & $3(60)$ & $2(100)$ \\
\hline $\mathbf{3}$ & Cefodroxil & $42(45.1)$ & $13(46.42)$ & $5(45.45)$ & $2(40)$ & $1(50)$ \\
\hline $\mathbf{4}$ & Cefoperazone & $56(58.34)$ & $16(57.14)$ & $5(45.54)$ & $5(100)$ & $1(50)$ \\
\hline $\mathbf{5}$ & Ceftazidime & $39(40.62)$ & $10(35.71)$ & $4(36.36)$ & $2(40)$ & $1(50)$ \\
\hline $\mathbf{6}$ & Ceftazidime / clavulaunic acid & $63(65.62)$ & $18(64.28)$ & $7(63.63)$ & $3(60)$ & $1(50)$ \\
\hline $\mathbf{7}$ & Cefotaxime & $45(46.87)$ & $13(46.42)$ & $5(45.54)$ & $3(60)$ & $1(50)$ \\
\hline $\mathbf{8}$ & Aztreonam & $57(59.37)$ & $16(57.14)$ & $6(54.54)$ & $3(60)$ & $1(50)$ \\
\hline $\mathbf{9}$ & Cefipime & $42(43.75)$ & $13(46.42)$ & $5(45.54)$ & $3(60)$ & $1(50)$ \\
\hline $\mathbf{1 0}$ & Amikacin & $67(69.79)$ & $20(71.42)$ & $8(72.72)$ & $5(100)$ & $2(100)$ \\
\hline $\mathbf{1 1}$ & Cotrimoxazole & $29(30.20)$ & $10(35.71)$ & $4(36.36)$ & $2(40)$ & $1(50)$ \\
\hline $\mathbf{1 2}$ & Levofloxacin & $46(47.91)$ & $15(53.57)$ & $3(27.27)$ & $3(60)$ & $2(100)$ \\
\hline $\mathbf{1 3}$ & Imipenem & $85(88.54)$ & $27(96.42)$ & $7(63.63)$ & $5(100)$ & $2(100)$ \\
\hline $\mathbf{1 4}$ & Piperacillin / Tazobactum & $77(80.20)$ & $26(92.85)$ & $7(63.63)$ & $5(100)$ & $1(50)$ \\
\hline $\mathbf{1 5}$ & Colistin & $90(93.75)$ & $26(92.85)$ & $6(54.54)$ & NA & $2(100)$ \\
\hline $\mathbf{1 6}$ & Tigecycline & $85(88.54)$ & $24(85.71)$ & NA & $5(100)$ & $2(100)$ \\
\hline $\mathbf{1 7}$ & Meropenem & $85(88.54)$ & $27(96.42)$ & $7(63.63)$ & $4(80)$ & $2(100)$ \\
\hline
\end{tabular}

*NA=Not applicable 
Table.6 Antibiotic sensitivity of gram-positive isolates

\begin{tabular}{|c|c|c|c|c|c|c|}
\hline \multirow[t]{2}{*}{ S.No. } & \multirow[t]{2}{*}{ Antibiotics } & \multicolumn{2}{|c|}{$\begin{array}{c}\text { Staphylococcus } \\
\text { aureus }\end{array}$} & \multirow[t]{2}{*}{$\begin{array}{c}\text { MRCONS } \\
n=4\end{array}$} & \multirow[t]{2}{*}{$\begin{array}{c}\text { MSCONS } \\
\mathrm{n}=9\end{array}$} & \multirow{2}{*}{$\begin{array}{c}\text { Streptococccus } \\
\text { pyogenes } \\
\mathrm{n}=1\end{array}$} \\
\hline & & $\begin{array}{c}\text { MRSA } \\
\mathrm{n}=14\end{array}$ & $\begin{array}{c}\text { MSSA } \\
n=83\end{array}$ & & & \\
\hline 1 & Penicillin & 0 & $18(21.68)$ & 0 & $2(22.23)$ & $1(100)$ \\
\hline 2 & Azithromycin & $7(50)$ & $33(39.75)$ & $2(50)$ & $6(66.67)$ & $1(100)$ \\
\hline 3 & Amikacin & $\begin{array}{c}10 \\
(71.42)\end{array}$ & 75 (90.36) & $3(75)$ & $9(100)$ & $1(100)$ \\
\hline 4. & Cefoxitin & 0 & $83(100)$ & 0 & $9(100)$ & $1(100)$ \\
\hline 5. & Ciprofloxacin & $7(50)$ & 47 (56.62) & $4(100)$ & $5(55.56)$ & $1(100)$ \\
\hline 6 & Vancomycin & $14(100)$ & $83(100)$ & $4(100)$ & $9(100)$ & $1(100)$ \\
\hline 7 & Linezolid & $14(100)$ & $83(100)$ & $4(100)$ & $9(100)$ & $1(100)$ \\
\hline 8 & Teicloplanin & $\begin{array}{c}10 \\
(71.42)\end{array}$ & $73(87.95)$ & $3(75)$ & 7 (77.78) & $1(100)$ \\
\hline 9 & Doxycycline & $14(100)$ & 73 (87.95) & $3(75)$ & 7 (77.78) & $1(100)$ \\
\hline 10 & Cotrimoxazole & $3(21.42)$ & $25(30.12)$ & $1(25)$ & $4(44.45)$ & $1(100)$ \\
\hline 11 & Daptomycin & $\begin{array}{c}10 \\
(71.42)\end{array}$ & $71(85.54)$ & $3(75)$ & $6(66.67)$ & NA \\
\hline 12 & Pristinomycin & $\begin{array}{c}10 \\
(71.42)\end{array}$ & $71(85.54)$ & $3(75)$ & $6(66.67)$ & NA \\
\hline 13 & $\begin{array}{l}\text { Piperacillin / } \\
\text { Tazobactum }\end{array}$ & $\begin{array}{c}10 \\
(71.42)\end{array}$ & $83(100)$ & $1(25)$ & $9(100)$ & NA \\
\hline 14 & Meropenem & $\begin{array}{c}12 \\
(85.71)\end{array}$ & $75(90.36)$ & $3(75)$ & $8(88.89)$ & NA \\
\hline
\end{tabular}

*NA=Not applicable

In this study, out of 410 pus samples collected and analyzed for bacterial growth, 257 (62.68\%) samples were found to be culture positive. Highest number of samples were from department of general surgery $(n=113)$ followed by casualty $(n=44)$ and plastic surgery $(n=38)$. Majority of the samples were of patients in the age group of 21-30 years. Additionally, male patients $(n=230)$ were higher in number than females $(n=180)$. Biradar et al., has shown similar results with males comprising majority of the study samples. ${ }^{(10)}$

From 257 growth positive samples, 12 different species of bacteria were identified, out of which $56.78 \% \quad(n=146)$ were gram negative and $43.16 \% \quad(n=111)$ were gram positive. The predominant presence of aerobic gram negative isolates compared to gram positive has been supported by previous studies conducted by Ghosh et al., and Zubair et al. ${ }^{(11,12)}$ Furthermore, almost all studies conducted in developing countries like India and Africa, have reported more growth of the gram negative isolates compared to gram positive bacterial isolates in pus samples. ${ }^{(10,13,14)}$

Different gram negative bacteria identified from pus cultures were as follows: E. coli, Klebsiella sp., Acinetobacter, Pseudomonas 
sp., and Proteus sp. Streptococcus sp., Staphylococcus aureus, MRSA, MSSA, MSCONS, Citrobacter and Proetus sp. were the gram positive bacteria to be isolated from pus cultures. The most frequently found pathogens were Staphylococcus aureus $(\mathrm{n}=97)$ and Klebsiella spp $(\mathrm{n}=96)$, which belongs to the gram positive and negative bacteria respectively. This is followed by E.coli $\quad(n=28), \quad$ CoNS $\quad(n=13) \quad$ and Pseudomonas spp $(\mathrm{n}=11)$. Studies conducted by Mantravadi et al., Lee et al., and Rao et al., has also reported Staphylococcus aureus to be the most frequently isolated bacterial pathogen from pus cultures. ${ }^{(15,16,17)}$ In contrast to results presented in this study, Aghnihotri et al., Duggal Swati et al., and Basu et al., has reported Pseudomonas to be the most commonly isolated pathogen which is followed by Staphylococcus. ${ }^{(18,19,20)}$ Another study by Rameshkannan et al., found E.coli to be the most frequently isolated organism from pus cultures. ${ }^{(21)}$

Among Staphylococcus aureus $75.45 \%$ isolates were MSSA and the rest $12.72 \%$ were MRSA. Staphylococcus aureus showed highest sensitivity for vancomycin (100\%), linezolid (100\%) and doxycycline (100\%). Chauhan et al., and Jain et al., has reported similar results regarding antibiotic sensitivity of the Staph. aureus, where it showed higher sensitivity for aminoglycosides such as vancomycin and clindamycin. ${ }^{(22,23)}$ Taiwo et al., showed highest sensitivity for vancomycin $(100 \%)$ and slightly less for linezolid $(98 \%)^{(24)}$. However, Hanumanthappa et al., has shown slightly lesser sensitivity of vancomycin $(87.3 \%)$ among Staph. aureus. ${ }^{(25)}$ The gram negative isolates were most sensitive towards impenem (86.30\%) followed by meropenem $(85.61 \%)$ and colistin $(83.56 \%)$. Rao et al., has reported similar results with imipenem showing highest sensitivity among gram negative isolates. ${ }^{(17)}$
In conclusion, pyogenic infections are one of the cardinal causes of morbidity across the globe. There is a growing concern regarding the treatment of such infections as the multidrug resistant strains are evolving rapidly, thereby delaying the recovery of the infected individuals. The present study has shown that though the Staphylococcus aureus remains to be the dominant cause of such infections, the role of the gram negative isolates cannot be diminished. Antibiotic resistance further complicates the treatment. Thus, an empirical therapy based on the sensitivity data helps clinicians to select the appropriate antibiotic for the pathogen. Our study helps clinicians in selecting the antibiotics that are susceptible for the bacteria and also in preventing further resistance among pathogens by its appropriate use.

\section{Limitations}

In this study only limited drugs were analyzed for the sensitivity of antibiotics in various microorganisms in a single hospital setting. However, multi-center study with larger sample size will provide significant results. Further, constantly changing antibiotic resistance patterns in bacteria requires periodic monitoring of their sensitivity profile.

\section{Conflict of interest}

Authors have no conflict of interest.

\section{Source of funding}

The present work has not been funded by any institute or organization.

\section{References}

1. Collier M (2003). Understanding wound inflammation. Nurs. times 99(25): 63-64.

2. Cogen AL, Nizet V, Gallo RL. Skin 
microbiota: a source of disease or defense? British Journal of Dermatology 2008; 158(3): 442-455

3. Esposito $S$, Noviello $S$, Leone $S$ Epidemiology and microbiology of skin and soft tissue infections. Curr Opin Infect Dis. 2016 Apr; 29(2):109-15

4. A. L. Cogen, V. Nizet, and R. L. Gallo, "Skin microbiota: a source of disease or defence?" British Journal of Dermatology, vol. 158, no. 3, pp. 442455, 2008.

5. M. S. Dryden, "Complicated skin and soft tissue infection," Journal of Antimicrobial Chemotherapy, vol. 65, supplement 3,pp. iii35-iii44, 2010.

6. R. M. Mordi and M. I. Momoh, "Incidence of Proteus species in wound infections and their sensitivity pattern in the University of Benin Teaching Hospital," African Journal of Biotechnology, vol. 8, no. 5, pp. 725-730, 2009.

7. Courvalin P. Antimicrobial Drug Resistance: Prediction Is Very Difficult, especially about the Future. Emerg Infect Dis. 2005;11:1503-06

8. J. Iredell, J. Brown, and K. Tagg, "Antibiotic resistance in Enterobacteriaceae: mechanisms and clinical implications," British Medical Journal, vol. 352, Article ID h6420, 2016.

9. E. Cerceo, S. B. Deitelzweig, B. M. Sherman, and A. N. Amin, "Multidrugresistant gram-negative bacterial infections in the hospital setting: overview, implications for clinical practice, and emerging treatment options," Microbial Drug Resistance, vol. 22, no. 5, pp. 412-431, 2016.

10. Biradar A, Farooqui F, Prakash R, Khaqri SY, Itagi I. Aerobic bacteriological profile with antibiogram of pus isolates. Indian J Microbiol Res 2016; 3(3): 245249.
11. Ghosh A, Karmakar PS, Pal J, Chakraborty N, Debnath NB, Mukherjee JD. Bacterial incidence and antibiotic sensitivity pattern in moderate and severe infections in hospitalized patients. $J$ Indian Med Assoc; 107(1): 21-2, 24-5 (2009).

12. Zubair M, Malik A, Ahmad J. Clinicomicrobiological study and antimicrobial drug resistance profile of diabetic foot infections in north India. Foot (Edinb) 2011; 21(1):6-14.

13. Rugira Trojan, Lovely Razdan, and Nasib Singh, "Antibiotic Susceptibility Patterns of Bacterial Isolates from Pus Samples in a Tertiary Care Hospital of Punjab, India," International Journal of Microbiology, vol. 2016, Article ID 9302692,4 pages, 2016.

14. Muluye et al.: Bacterial isolates and their antibiotic susceptibility patterns among patients with pus and/or wound discharge at Gondar university hospital. BMC Research Notes 2014 7:619.

15. Mantravadi HB, Chinthaparthi MR, Shravani V. Aerobic isolates in pus and their antibiotic sensitivity pattern: a study conducted in a teaching hospital in Andhra Pradesh. International Journal of Medical Science and Public Health. 2015 Aug 1;4(8):1076-80

16. Lee CY, Chen PY, Huang FL, Lin CF .Microbiology spectrum and susceptibility pattern of clinical isolates from the pediatric intensive care in the simple medical centre- 6 years experience. J Microbiol Immunol Infect, 2009; 42(2): 160-5; 7.

17. Rao R, Biswas DR. Aerobic Bacterial Profile and Antimicrobial Susceptibility Pattern of Pus Isolates in a South Indian Tertiary Care Hospital. IOSR Journal of Dental and Medical Sciences, 2014; 5962.

18. Agnihotri N, Gupta V, Joshi RM. 2004. Aerobic bacterial isolates from burn 
wound infections and their antibiograms a five year study. Burns. 30(3): 241-3.

19. Duggal S, Khetri PK, Parihar RS, Arora R. Antibiogram of various Bacterial Isolation from Pus Sample in a Tertiary care centre in Rajasthan. International journal of science and research, 2013; 4: 438.

20. Basu S, Ramcharan Panray T, Bali Singh T, Gulati AK, Shukla VK, A; prospective, descriptive study to identify the microbiological profile of chronic wounds in Outpatients, Ostomy Wound manage, 2009; 55(1): 14-20

21. Rameshkannan S, Nileshraj G, Rameshprabu S, Mangaiarkkarasi A, Meher Ali R. Pattern of pathogens and their sensitivity isolated from pus culture reports in a tertiary care hospital, Puducherry. Indian Journal of Basic and Applied Medical Research, 2014; 4(1): $243-248$.

22. Chauhan M, Manish S and Mohajan S. Aerobic Bacterial Profile and antibiotic sensitivity pattern of pus isolates in a tertiary care hospital. Int. J. Curr. Microbiol. App. Sci, 2005; 4(5): 784787.

23. Jain V, Ramnani VK and Kaore N. Antimicrobial susceptibility pattern amongst aerobic bacteriological isolates in infected wounds of patients attending tertiary care hospital in Central India. Int. J. Curr. Microbiol. App. Sci. 2015; 4(5):711-719. 9.

24. Taiwo SS, Okesina AB, Onile BA. In vitro antimicrobial susceptibility pattern of bacterial isolates from wound infections in University of Ilorin teaching hospital. Afr J Clin Exp Microbiol 2002; 3(1): 6-10.

25. Hanumanthappa P, Vishalakshi B and Krishna S.A Study on aerobic Bacteriological profile and Drug sensitivity pattern of Pus samples in a tertiary care hospital. Int. J. Curr. Microbiol. App. Sci. 2016;5(1):95-102.

\section{How to cite this article:}

Qursheed Sultana, Ajaz Hussain, Maimoona Mustafa and Mohammed Abdur Rab Ansari. 2020. Bacteriological Profile and Antibiotic Sensitivity Pattern of Bacterial Pathogens Isolated from Pus Samples. Int.J.Curr.Microbiol.App.Sci. 9(07): 114-122. doi: https://doi.org/10.20546/ijcmas.2020.907.013 